\title{
A systematic review of post-migration acquisition of HIV among migrants from countries with generalised HIV epidemics living in Europe: mplications for effectively managing HIV prevention programmes and policy
}

Ibidun Fakoya ${ }^{1 *}$, Débora Álvarez-del Arco ${ }^{2,4}$, Melvina Woode-Owusu', Susana Monge ${ }^{3,4}$, Yaiza Rivero-Montesdeoca ${ }^{2,4}$, Valerie Delpech ${ }^{5}$, Brian Rice ${ }^{5}$, Teymur Noori ${ }^{6}$, Anastasia Pharris ${ }^{6}$, Andrew J. Amato-Gauci ${ }^{6}$, Julia del Amo ${ }^{2,4}$ and Fiona M. Burns ${ }^{1,7}$

\begin{abstract}
Background: Migrant populations from countries with generalised HIV epidemics make up a significant proportion of all HIV/AIDS cases in many European Union and European Economic Area (EU/EEA) countries, with heterosexual transmission the predominant mode of HIV acquisition. While most of these infections are diagnosed for the first time in Europe, acquisition is believed to have predominantly occurred in the home country. A proportion of HIV transmission is believed to be occurring post-migration, and many countries may underestimate the degree to which this is occurring. Our objectives were to review the literature estimating the proportion of migrants believed to have acquired their HIV post-migration and examine which EU member states are able to provide estimates of probable country of HIV acquisition through current surveillance systems.

Methods: A systematic review was undertaken to gather evidence of sexual transmission of HIV within Europe among populations from countries with a generalised epidemic. In addition, national surveillance focal points from 30 EU/EEA Member States were asked to complete a questionnaire about surveillance methods and monitoring of the likely place of HIV acquisition among migrants.

Results \& discussion: Twenty-seven papers from seven countries were included in the review and 24 countries responded to the survey. Estimates of HIV acquisition post-migration ranged from as low as $2 \%$ among sub Saharan Africans in Switzerland, to $62 \%$ among black Caribbean men who have sex with men (MSM) in the UK. Surveillance methods for monitoring post-migration acquisition varied across the region; a range of methods are used to estimate country or region of HIV acquisition, including behavioural and clinical markers. There is little published evidence addressing this issue, although Member States highlight the importance of migrant populations in their epidemics. (Continued on next page)
\end{abstract}

\footnotetext{
*Correspondence: ibidun.fakoya@ucl.ac.uk

${ }^{1}$ Centre for Sexual Health and HIV Research, Research Department of Infection and Population Health, University College London, Mortimer Market Centre, off Capper Street, London WC1E 6JB, UK

Full list of author information is available at the end of the article
} 
(Continued from previous page)

Conclusions: There is post-migration HIV acquisition among migrants in European countries but this is difficult to quantify accurately with current data. Migrant MSM appear at particular risk of HIV acquisition post-migration. Countries that identify migrants as an important part of their HIV epidemic should focus on using an objective method for assigning probable country of HIV acquisition. Robust methods to measure HIV incidence should be considered in order to inform national prevention programming and resource allocation.

Keywords: Migrants, Sexually transmitted diseases, Surveillance, Epidemiology, HIV prevention, Europe, Prevention \& control, Migrant MSM, Sexual behaviour

\section{Background}

A large proportion of people living with HIV/AIDS in most European Union/European Economic Area (EU/ EEA) countries are migrants, that is, people currently living outside their country of birth [1]. In 2013, around one third (33\%; 3 160) of those in EU/EEA who were reported to have contracted HIV through heterosexual contact were migrants from countries with generalised HIV epidemics (mainly sub Saharan Africa) [2]. While most of these diagnoses were made for the first time in Europe, HIV acquisition is predominantly assumed to have occurred in the home country [3].

This assumption is often based on reports from clinicians who make deductive inferences according to a patient's country of birth, time of arrival in the new country of residence, CD4 cell counts and the natural history of HIV infection. Clinicians may also use algorithms that are biased towards determining that patients born in countries with a generalised epidemic contracted HIV prior to migrating to Europe [4]. Often these estimates do not take into account additional factors. For example, it has been reported that CD4 cell counts close to seroconversion are considerably lower among those living with non-B HIV-1 viral subtypes, which are most common among migrants from outside Europe, particularly in Sub-Saharan Africa. [3, 5, 6]. Consequently, a lower CD4 cell value at diagnosis in those with non-B sub-types may wrongly suggest that individuals have been living with HIV for longer than they have; leading to the conclusion that HIV was acquired before migration. The presence of non-B subtypes among Europeborn populations may also be interpreted as evidence of sexual mixing between migrants and non-migrants.

Funding for primary prevention among migrant communities may be reduced or redirected if surveillance data suggest that individuals do not have HIV prevention needs after they have left their home country or that significant numbers of migrants are coming to Europe as "HIV health tourists" $[7,8]$. There have been no previous efforts to collate the information about the proportion of people from countries with a generalised epidemic that contract HIV post-migration. If programme managers and policy-makers underestimate the degree of HIV acquisition within the
EU/EEA for migrants from countries with generalised epidemics this may undermine the potential for reducing HIV prevalence and incidence through targeted primary and secondary prevention programmes and policy.

This paper presents a review of the evidence of postmigration HIV acquisition among migrants from countries with a generalised epidemic living in Europe. We examine quantitative studies and surveillance reports based on data on populations from countries with a generalised epidemic which include outcomes that estimate the probable country of acquisition, incident infections, or evidence of sexual mixing. In addition this paper profiles the ability of EU Member States surveillance systems to provide accurate monitoring information about probable country of HIV acquisition. We discuss the implications of these results in HIV prevention programming and policy across the EU/EEA region.

\section{Methods}

\section{Systematic review}

Nine electronic databases (Allied and Complementary Medicine; Cochrane Database of Systematic Reviews; Cumulative Index to Nursing \& Allied Health Literature; Database of Abstracts of Reviews of Effects; EMBASE; Health Management Information Consortium; Health Technology Assessment; Medline; PsychInfo) were searched during May 2012 ${ }^{1}$. A detailed search strategy was used which combined synonyms for "HIV", "migrant", "assortative sexual mixing", "sexual transmission" with demonyms for all countries with a generalised HIV epidemic (for the complete list search terms, a full description the review protocol please see report [9]). Searches were limited to studies conducted between 01/0/1/2002 and 31/12/2014 to provide the most up-to-date estimates. Studies written in English, French, Italian, Portuguese and Spanish were included. Additional grey literature was retrieved from four websites (United Nations Department of Economic and Social Affairs Population Division; European Health for All database, World Health Organization Regional Office for Europe; European Centre for Disease Prevention and Control), and relevant data were requested from individuals participating in the Member States Survey (see below). The 
search process was documented by compiling the search strategies used to explore each resource.

\section{Selection criteria}

Only studies conducted in countries with programmatic or surveillance links within the European Centre for Disease Prevention and Control (ECDC) were included in this re$v^{2} w^{2}$. Studies were eligible for inclusion if: the study population included migrant men or women from countries with a generalised HIV-1 epidemic AND the study included sub-group analysis based on race/ethnicity or country/ region of origin OR at least $80 \%$ of the study populations were from countries with a generalised HIV epidemic. Studies were only included if they reported on any of the following outcomes: proportion of target population infected with HIV in country of origin; proportion of target population infected in country of migration; estimate of incident HIV infections (not diagnoses) in target population in country of migration; probable country of infection/HIV acquisition and evidence of sexual mixing. Studies that reported mode of transmission but made no reference to whether sexual transmission took place pre- or postmigration were excluded at full paper screening stage. Qualitative studies (using in-depth interviews, focus group discussions, and document analysis), conference communications, pilots or feasibility studies were excluded.

\section{Quality assessment}

Studies were selected using a two-stage screening approach. Reviewers devised a checklist to independently screen all retrieved titles and abstracts. Studies were given an overall quality score which incorporated a number of factors drawn from the PRISMA [10] and NICE guidelines [11] including risk of bias, internal and external validity (See Table 1). Papers were graded as having an overall quality score of "Low", "Medium" or "High". We were aware that within this review few cohort or intervention studies would be retrieved which may lead to a systemic bias in quality assessment. As a result studies were rated within the paradigm of their study type and studies based on surveillance or cross sectional data were able to achieve overall quality scores of "Medium" or "High". Studies that received a "Low" score or for which no information to perform quality assessment was available were excluded from the final review. Inter-reviewer reliability scores (Cohen $\mathrm{K}$ ) were calculated using Kappa in Microsoft Excel: a kappa of 0.68 for full paper screening and 0.64 for quality appraisal, indicated a high level of agreement between reviewers.

\section{Data extraction and analysis}

Data were extracted using forms detailing study objectives; thematic areas; data collection; methodology (design; setting; population; sample size; geographical
Table 1 Criteria used to assess the quality of papers included in full paper review

Criterion 1: Research question

Paper is based on a clearly defined research question, which is clearly discussed and referenced throughout the paper.

Criterion 2: Internal Validity

The study design was appropriate for the research question and stated study objectives. Selection bias has been minimised; confounding factors have been identified and/or controlled; explanatory variables are based on sound scientific principles; outcome measures are complete and reliable.

Criterion 3 Clarity of Results

Results well described and clear appropriate analytical methods used. The precision of association is given or calculable and is meaningful.

Criterion 4: External Validity

Source population is well described and the eligible population represent the source population. Selected participants represent eligible population and the results are consistent with results from other studies. The study results are generalisable to the source population.

Criterion 5: Strength of Association and Statistical Significance

The study sufficiently powered and precise outcomes have been measured. There are narrow confidence intervals and/or low p-values

scope); results and outcomes (n or \%); author defined strengths and limitations and gender specific issues. After data extraction for each paper, studies were grouped according to outcomes of interest. Narrative summaries of each outcome of interest are presented.

\section{Member states survey}

During August 2012, a survey was conducted among 30 EU/EEA Member states using an online survey software package SelectSurveyNet (ClassApps). The questionnaire was developed to gather information from representatives of each member state regarding their knowledge and surveillance of HIV and HIV transmission among migrants from countries with a generalised HIV epidemic. Nationally nominated HIV surveillance contact points were invited to complete the short, 14-item questionnaire which contained mainly open questions, allowing respondents to provide detailed responses. Survey questions were tailored to each country based on information that had been recently submitted to ECDC as part of the Dublin Declaration reporting process $^{3}$. Participants were also able to upload documents to support their responses and these documents were added to the systematic literature review process described above.

\section{Results}

In total 8125 documents were retrieved from all sources. Twenty-seven peer-reviewed papers (representing 26 studies) were found to fulfil the inclusion and quality assessment criteria and were therefore included in the final review. Fig. 1 summarises the outcome of the paper selection process. 


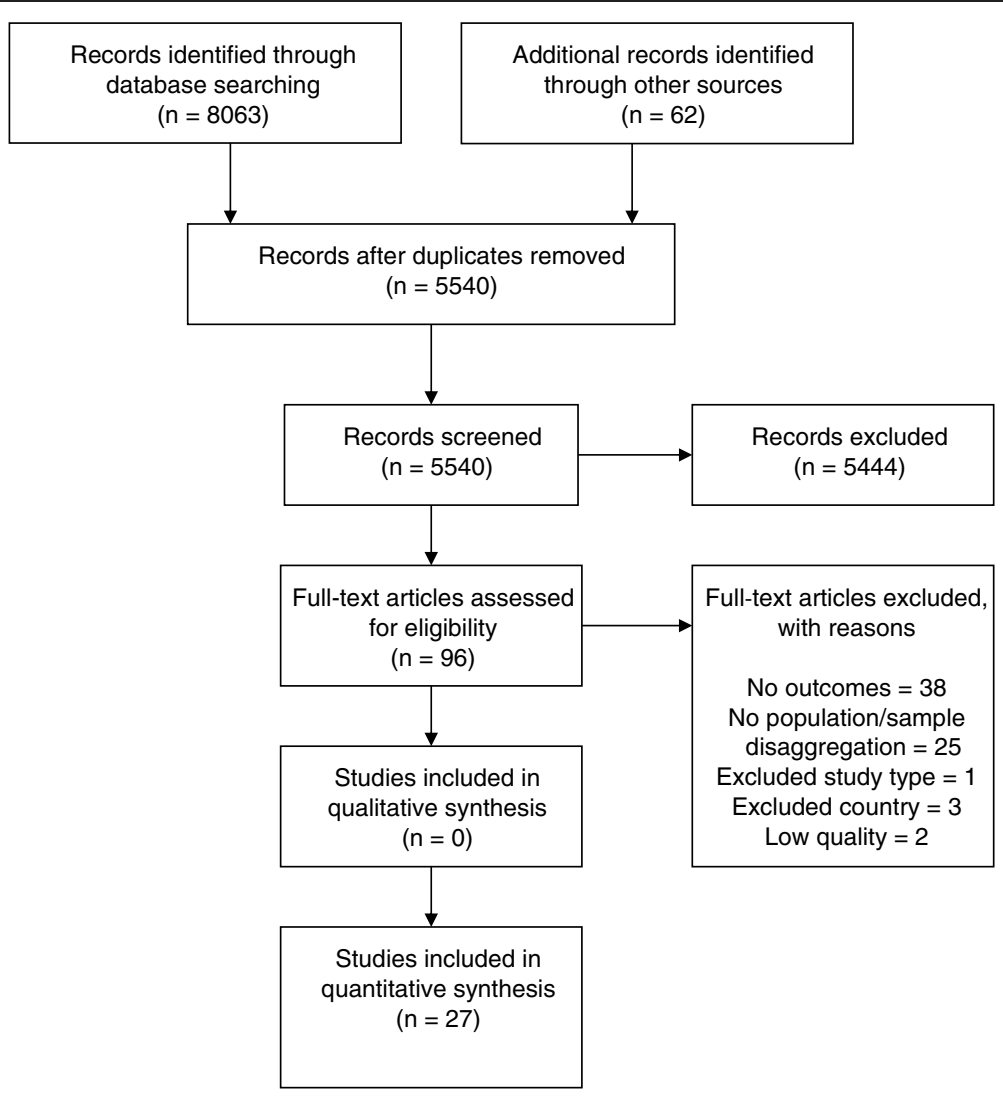

Fig. 1 Summary of study selection process

Papers were included from six EU countries: United Kingdom (9); Netherlands (4); France (4); Spain (2); Belgium (1) and Italy (3). Two papers were also included from Switzerland and two further papers covered the entire European region. Studies were grouped according to outcomes of interest within three categories: Probable country of HIV acquisition; Estimates of incident HIV infections; and Evidence of sexual mixing. Tables 2 and 3 summarise the 26 studies' characteristics and includes the quality appraisal process results.

\section{Probable country of HIV acquisition and estimates of incident HIV infection}

Estimates of probable country of infection and/or estimates of incident infection were found in 18 of the 27 papers selected for systematic review. In most of the papers, the study population included people from countries not considered to have a generalised HIV epidemic, but data were disaggregated which allowed reviewers to perform data extraction and compare data across countries. The estimates varied both within countries and across Europe, and covered a range of subgroups, including men who have sex with men (MSM) as well as heterosexuals. Table 4 shows the proportion of infections acquired among sub
Saharan Africans post-migration in France, Netherlands, Switzerland and the UK. Table 5 shows infections acquired post-migration among individuals from the Caribbean and Asia in Italy, Netherlands, Switzerland and the UK.

While the generilisability and validity of all these papers were medium or high, there are some limitations to the data presented (Table 3). Data estimating the proportion of post-migration HIV acquisition from cross sectional studies in France, Italy, Switzerland and the UK relied on samples that were either very small [12] or were reported to be possibly biased and unrepresentative of the wider population from which the samples were drawn [13-15]. Estimates from The Netherlands were derived from mathematical models. The authors provided very little information about the data used to source the models nor did they discuss the consequent limitations such data placed on the models $[16,17]$.

Using a new method to ascertain likely country of HIV infection, the UK recently published estimates of place of HIV acquisition among 10,612 heterosexual migrants (9065 of black-African ethnicity) diagnosed with HIV in the UK between 2004 and 2010 [18]. The authors used CD4 at diagnosis to estimate year of infection for each of the adults in their study population and taking into 
Table 2 Summary of included studies: population characteristics

\begin{tabular}{|c|c|c|c|c|c|}
\hline Study reference & Study type & Country & Population & Methods & Sample size \\
\hline \multicolumn{6}{|c|}{ Probable country of infection and Estimates of incident infection } \\
\hline $\begin{array}{l}\text { Aggarwal et al. } \\
\text { (2006) [32] }\end{array}$ & CS & UK & $\begin{array}{l}\text { Black African, white UK-born, } \\
\text { and black Caribbean patients }\end{array}$ & $\begin{array}{l}\text { Review of key epidemiologic } \\
\text { data obtained from the medical } \\
\text { records or from patient's physician }\end{array}$ & $\begin{array}{l}344 \text { (total) } 154 \text { (black African) } \\
42 \text { (black Caribbean) }\end{array}$ \\
\hline $\begin{array}{l}\text { Burns et al. } \\
\text { (2009) [38] }\end{array}$ & CS & UK & $\begin{array}{l}\text { HIV-positive Africans within } \\
12 \text { months of initial HIV } \\
\text { diagnosis and aged } 18 \text { years } \\
\text { or more }\end{array}$ & $\begin{array}{l}\text { Data for all respondents to } \\
\text { survey ranked for likelihood of } \\
\text { acquisition in the UK or abroad }\end{array}$ & 263 \\
\hline $\begin{array}{l}\text { del Amo et al. } \\
\text { (2011) [31] }\end{array}$ & $\begin{array}{l}\text { Systematic } \\
\text { review }\end{array}$ & Europe & $\begin{array}{l}\text { Migrant populations/Ethnic } \\
\text { minorities }\end{array}$ & $\begin{array}{l}\text { Literature review of the five main } \\
\text { databases of articles in English } \\
2005-2009\end{array}$ & 37 articles \\
\hline $\begin{array}{l}\text { Dougan et al. } \\
\text { (2005) [39] }\end{array}$ & Surveillance & UK & $\begin{array}{l}\text { BME MSM newly diagnosed } \\
\text { with HIV in E\&W between } \\
1997 \text { and } 2002\end{array}$ & $\begin{array}{l}\text { Review of data from two national } \\
\text { HIV/AIDS surveillance systems. } \\
\text { Undiagnosed HIV prevalence } \\
\text { examined by world region of birth }\end{array}$ & 1040 \\
\hline $\begin{array}{l}\text { Dougan et al. } \\
\text { (2004) [40] }\end{array}$ & Surveillance & UK & Black Caribbean adults & $\begin{array}{l}\text { Analysis of voluntary confidential } \\
\text { reports of new diagnoses received } \\
\text { from virologists and clinicians }\end{array}$ & 528 \\
\hline $\begin{array}{l}\text { Dougan et al. } \\
\text { (2005) [15] }\end{array}$ & Surveillance & UK & MSM & $\begin{array}{l}\text { Analysis of reports of diagnoses from } \\
\text { laboratories (since 1985) and clinicians } \\
\text { (since 2000) }\end{array}$ & 6386 MSM (total) \\
\hline $\begin{array}{l}\text { Hamers \& Downs } \\
\text { (2004) [41] }\end{array}$ & Surveillance & Europe & $\begin{array}{l}\text { People living with diagnosed } \\
\text { HIV in } 12 \text { European countries }\end{array}$ & $\begin{array}{l}\text { Review of HIV/AIDS surveillance } \\
\text { databases maintained by EuroHIV } \\
\text { network }\end{array}$ & $\begin{array}{l}542,380 \text { (total) 14,077 (migrants } \\
\text { from countries with generalised } \\
\text { epidemic) }\end{array}$ \\
\hline $\begin{array}{l}\text { Lot et al. } \\
\text { (2004) [14] }\end{array}$ & Surveillance & France & $\begin{array}{l}\text { Newly diagnosed HIV } \\
\text { positive men and women }\end{array}$ & $\begin{array}{l}\text { Analysis of HIV reports confirmed by } \\
\text { laboratories; supplemented by } \\
\text { epidemiological and clinical data }\end{array}$ & 1301 \\
\hline $\begin{array}{l}\text { Pezzoli et al. } \\
\text { (2009) [12] }\end{array}$ & CS & Italy & $\begin{array}{l}\text { All adult migrants from a } \\
\text { non-EU country registered } \\
\text { at primary healthcare centres }\end{array}$ & $\begin{array}{l}\text { Structured questionnaire; included } \\
\text { HIV testing; conducted in three } \\
\text { cities: Brescia, Rome, Palermo }\end{array}$ & $\begin{array}{l}3003 \text { (total) } 674 \text { (sub Saharan } \\
\text { Africans) }\end{array}$ \\
\hline $\begin{array}{l}\text { Rice et al. } \\
\text { (2012) [18] }\end{array}$ & Surveillance & UK & $\begin{array}{l}\text { Heterosexual adults born } \\
\text { abroad and diagnosed with } \\
\text { HIV in the UK }\end{array}$ & $\begin{array}{l}\text { National surveillance data analysed; } \\
\text { year of infection assigned based } \\
\text { on mathematical model }\end{array}$ & $\begin{array}{l}10,612 \text { (total) } 9065 \text { (black } \\
\text { African) }\end{array}$ \\
\hline $\begin{array}{l}\text { Rice et al. } \\
(2014) \text { [19] }\end{array}$ & Surveillance & UK & $\begin{array}{l}\text { Newly diagnosed heterosexual } \\
\text { adults seen in care in the UK }\end{array}$ & $\begin{array}{l}\text { National surveillance data analysed } \\
\text { for trend changes in probable } \\
\text { country of infection. }\end{array}$ & $\begin{array}{l}37,984 \text { (total) 22,524 (black } \\
\text { African born abroad) }\end{array}$ \\
\hline $\begin{array}{l}\text { Semaille et al. } \\
\text { (2008) [13] }\end{array}$ & Surveillance & France & $\begin{array}{l}\text { Newly diagnosed HIV } \\
\text { positive men and women }\end{array}$ & $\begin{array}{l}\text { Analysis of all mandatory anonymous } \\
\text { HIV case reports mid-2003 -2006 }\end{array}$ & $\begin{array}{l}10,855 \text { (total) } 2,511 \text { (confirmed } \\
\text { recent infections) }\end{array}$ \\
\hline $\begin{array}{l}\text { Sinka K et al. } \\
(2003)[4]\end{array}$ & Surveillance & UK & People diagnosed with HIV & $\begin{array}{l}\text { Analysis of voluntary confidential } \\
\text { reports of new diagnoses received } \\
\text { from virologists and clinicians }\end{array}$ & $\begin{array}{l}\text { 48,226 (total) } 8960 \text { (probably } \\
\text { acquired in Africa) }\end{array}$ \\
\hline $\begin{array}{l}\text { Staehelin et al. } \\
\text { (2004) [42] }\end{array}$ & $\begin{array}{l}\text { Retrospective } \\
\text { cohort }\end{array}$ & Switzerland & All migrant patients 1984-2000 & $\begin{array}{l}\text { Single centre retrospective cohort: } \\
\text { Time of HIV-infection estimated } \\
\text { using CD4 cell count, CD4 cell } \\
\text { decline over time and plasma } \\
\text { RNA level }\end{array}$ & 1215 (total) \\
\hline $\begin{array}{l}\text { Valin, et al. } \\
\text { (2004) [43] }\end{array}$ & CS & France & $\begin{array}{l}\text { Sub Saharan Africans, aged } \\
18+\text { presenting with HIV at } \\
\text { outpatient or inpatient } \\
\text { appointments }\end{array}$ & $\begin{array}{l}\text { Structured questionnaire collecting } \\
\text { socio-demographic \& clinical data }\end{array}$ & 250 \\
\hline $\begin{array}{l}\text { von Wyl V et al. } \\
(2011)^{*}[20]\end{array}$ & $\begin{array}{l}\text { Prospective } \\
\text { cohort }\end{array}$ & Switzerland & $\begin{array}{l}\text { Patients who received their } \\
\text { HIV diagnosis between } \\
1 \text { January } 1996 \text { and } 31 \\
\text { December } 2009\end{array}$ & $\begin{array}{l}\text { Phylogenetic analysis - additional } \\
\text { demographic data from the Swiss } \\
\text { HIV Cohort Study database }\end{array}$ & $\begin{array}{l}1143 \text { individual infected with } \\
\text { HIV-1 subtypes A, C,CRF AE, AG }\end{array}$ \\
\hline \multirow[t]{2}{*}{$\begin{array}{l}\text { Xiridou et al. } \\
\text { (2010) [16] }\end{array}$} & $\begin{array}{l}\text { Mathematical } \\
\text { model }\end{array}$ & Netherlands & $\begin{array}{l}\text { African migrants, Caribbean } \\
\text { migrants, and 'general' } \\
\text { Dutch population }\end{array}$ & $\begin{array}{l}\text { Model parameterized using data } \\
\text { from several surveys including } \\
\text { two national surveys }\end{array}$ & N/A \\
\hline & & Netherlands & & & $\mathrm{N} / \mathrm{A}$ \\
\hline
\end{tabular}


Table 2 Summary of included studies: population characteristics (Continued)

\begin{tabular}{|c|c|c|c|c|c|}
\hline $\begin{array}{l}\text { Xiridou et al. } \\
\text { (2011) [17] }\end{array}$ & $\begin{array}{l}\text { Mathematical } \\
\text { model }\end{array}$ & & $\begin{array}{l}\text { African migrants, Caribbean } \\
\text { migrants, and the remaining } \\
\text { 'general' Dutch population }\end{array}$ & $\begin{array}{l}\text { Model describes transmission } \\
\text { of HIV in heterosexual partnerships }\end{array}$ & \\
\hline \multicolumn{6}{|c|}{ Evidence of sexual mixing } \\
\hline $\begin{array}{l}\text { Elford et al. } \\
(2007) \text { [26] }\end{array}$ & CS & UK & $\begin{array}{l}\text { Patients diagnosed HIV } \\
\text { infection aged } 18+\text { years }\end{array}$ & $\begin{array}{l}\text { Self-administered questionnaire to } \\
\text { patients in six east London public } \\
\text { hospitals }\end{array}$ & $\begin{array}{l}1687 \text { (total) } 704 \text { (black African } \\
\text { heterosexual) } 112 \text { (non-white } \\
\text { MSM) }\end{array}$ \\
\hline $\begin{array}{l}\text { Holguin et al. } \\
\text { (2007) [21] }\end{array}$ & CS & Spain & $\begin{array}{l}\text { Individuals newly diagnosed } \\
\text { with HIV-1 infection between } \\
1998 \text { and } 2004\end{array}$ & Chart review and data analysis & 429 (total) 87 (foreign born) \\
\hline $\begin{array}{l}\text { Kramer } \\
(2008)[29]\end{array}$ & CS & Netherlands & $\begin{array}{l}\text { Surinamese and Antillean } \\
\text { migrants (incl. 2nd gen) } \\
\text { aged 16-70 years }\end{array}$ & $\begin{array}{l}\text { Structured questionnaire administered } \\
\text { in social venues }\end{array}$ & 1938 \\
\hline Lai (2013) [24] & CS & Italy & $\begin{array}{l}\text { HIV positive patients } \\
\text { attending clinical centres }\end{array}$ & Phylogenetic analysis & $\begin{array}{l}254 \text { (total) } 114 \text { (Italy) } 60 \text { (Africa) } \\
12 \text { (South America) } 4 \text { (South } \\
\text { East Asia) } 64 \text { (other/unknown) }\end{array}$ \\
\hline $\begin{array}{l}\text { Marsicano et al. } \\
\text { (2013) [28] }\end{array}$ & CS & France & $\begin{array}{l}\text { Sub Saharan Africans, aged } \\
18-49 \text { living in the lle-de- } \\
\text { France }\end{array}$ & $\begin{array}{l}\text { Interviewer administered face-to-face } \\
\text { questionnaire }\end{array}$ & $\begin{array}{l}1874 \text { (total) } 973 \text { (women) } \\
901 \text { (men) }\end{array}$ \\
\hline Rivas (2013) [25] & $\begin{array}{l}\text { Prevalence } \\
\text { study }\end{array}$ & Spain & $\begin{array}{l}\text { Migrants from Equatorial } \\
\text { Guinea (EG) aged > }>16 \text { seen } \\
\text { for first consultation in in } \\
\text { clinic 2002-2008 }\end{array}$ & $\begin{array}{l}\text { Analysis HIV \& viral hepatitis } \\
\text { prevalence among EG migrants } \\
\text { compared to migrants from SSA }\end{array}$ & $\begin{array}{l}1493 \text { (total) } 1220 \text { (Equatorial } \\
\text { Guinea) } 276 \text { (other SSA } \\
\text { countries) }\end{array}$ \\
\hline $\begin{array}{l}\text { Snoeck et al. } \\
(2002)[22]\end{array}$ & CS & Belgium & Patients with diagnosed HIV & $\begin{array}{l}\text { Phylogenetic analysis \& retrospective } \\
\text { review of patient records }\end{array}$ & 41 (total, 18 \% African) \\
\hline $\begin{array}{l}\text { Tramutoet al } \\
\text { (2013) [23] }\end{array}$ & Surveillance & Italy & $\begin{array}{l}\text { ART Naïve HIV positive } \\
\text { patients attending care }\end{array}$ & $\begin{array}{l}\text { Laboratory hospital surveillance } \\
\text { data analysed }\end{array}$ & $\begin{array}{l}155 \text { (total) } 113 \text { (native Sicilian) } \\
42 \text { (migrants) }\end{array}$ \\
\hline $\begin{array}{l}\text { van Veen et al. } \\
\text { (2009) [27] }\end{array}$ & CS & Netherlands & $\begin{array}{l}\text { Migrants from Surinam, } \\
\text { Antilles, Cape Verde \& } \\
\text { Ghana, aged } 18-55\end{array}$ & $\begin{array}{l}\text { Individuals recruited in community } \\
\text { setting so self-complete structured } \\
\text { questionnaire }\end{array}$ & 1680 \\
\hline
\end{tabular}

$\mathrm{CS}=$ Cross Sectional Study; MSM = Men who have sex with men; BME = Black and Minority Ethnic *Also includes data on Sexual Mixing, E\&W = England and Wales

account the variable "Year of Migration", assigned probable place of HIV acquisition. The CD4-cell based method estimated that $33 \%$ of the study population (26 \%-39 \%) acquired HIV while living in the UK, three times higher than national estimates of HIV based on clinic reports $(11 \%)$. The study also found that the proportion of persons who had acquired their HIV while living in the UK had increased from 24\% (16-39\%) in 2004 to $46 \%(31 \%-50 \%$ in 2010 ( $\mathrm{p}<0.01)$. Similar analysis performed at a later point by the same authors estimated the increase among black African heterosexuals to be from $9.1 \%$ in 2002 to $37 \%$ in 2011 ( $<<0.01$ ), however this analysis included data based on clinical reports [19].

The authors discuss two major limitations with this method. First, the method cannot take into account travel (including vacations back to the country of origin) postmigration. Second, the method relies on key variables (CD4 counts, date of arrival and country of birth) and therefore it cannot be applied if these data are missing.

\section{Evidence of sexual mixing}

Fourteen studies examined sexual activity of people after they migrated to Europe (Table 2). Most studies used molecular epidemiology to describe the distribution of
non-B subtypes and HIV transmission networks, and in so doing provide estimates of sexual mixing. These studies show that non-B subtypes are prevalent among people born within and outside Europe: in Switzerland, the proportion of non-B subtype virus increased from $22 \%$ in 1996 to $33 \%$ in 2009 [20]; Holguin et al. (2007) [21] found that $53 \%$ of migrants and $14 \%$ of native Spaniards in their study in Grand Canary were infected with non-B strains; Snoeck et al. (2002) reported a small number of non-B subtypes originated in Belgium (16\%) [22]; in Italy Tramuto et al. (2013) estimate that less than one in ten Italian-born individuals in their study were living with non-B HIV-1 subtypes [23]. More detailed analysis from Lai et al. (2013) showed that country of origin was independently associated with the probability of patients being detected in epidemiological clusters, although patients from countries with a generalised epidemic were less likely to be detected than those from Italy or South America [24]. Rivas et al. (2013) provide some evidence of sexual mixing by reporting a small proportion of B subtypes (3.3\%) among migrants from sub Saharan Africa living in an area of Spain [25].

Elford et al. (2007) [26] state that $80 \%$ of black African heterosexuals reported sexual partners of the same 
Table 3 Outcomes and limitations of included studies

Aggarwal et al. (2006) [32] Distribution of non-B subtypes: Black African 149/154; Black Caribbeans $13 / 42$. Country of infection B subtypes: Black African 3 UK $(n=5)$; Black Caribbean 13 UK, 5 Caribbean, 11 undetermined $(n=29) \cdot$ Country of infection non-B subtypes: Black African 98 before migration, 14 UK, 34 undetermined $(n=149)$; Black Caribbean: $13 / 13$ UK • Overall infected in the UK: Black African 17/154 Black Caribbean: 26/42

Burns et al. (2009) [38]

Country of Acquisition: 61(23.2 \%) "Definitely acquired HIV abroad"; 44 (16.7\%) "Probably abroad"; 16 (6.1\%), "Definitely acquired in the UK"; 142 (54.4 \%) 'Indeterminate cases'. All cases (determinate and indeterminate): UK acquired: $25.1 \%$ - $35.4 \%$, Acquired abroad $60.8 \%$ - $67.3 \%$

del Amo et al. (2011) [33] Most studies among sub-Saharan African migrants report infections acquired in the country of origin; includes studies in Denmark, Spain, UK \& Canada. Some evidence of post-migration HIV acquisition in EU countries (includes Latin American MSM \& other migrant populations); Latin American MSM \& other migrant populations),
evidence of acquisition during return visits to country of origin.

Dougan et al. (2005) [39] New diagnosis: probable country of infection reported for $38 \%$ of BME MSM. Born outside and infected in the UK: $38 \%$ of black African (BA), $27 \%$ of black Caribbean (BC) - Born and infected outside the UK: $50 \%$ of BA, $37 \%$ of $\mathrm{BC} \cdot$ - Undiagnosed prevalence \% (CI): All BME 4.3 (4.1-4.5), BC 4.6 (3.3-6.2), BC 15.8 (11.7-20.8).

Dougan et al. (2004) [40] Heterosexual men infected in UK: 37 (country of birth unknown: 24) - Heterosexual women infected in UK 66 (country of birth unknown: 31 ) $\cdot$ MSM infected in the UK 48 (Country of birth unknown: 24).

Dougan et al. (2005) [15] Probable country of infection MSM born in Africa: Infected in Africa $=46.4 \%$; UK $=45.5 \%$; Other $=8.2 \% \cdot$ MSM born in Caribbean: Infected in Caribbean $=50.0 \%$; UK $=42.6 \%$; Other: $7.4 \% \cdot$ MSM born in Asia: Infected in Asia = $30.6 \%$; UK = 61.2\%;Other = $8.2 \%$.

Hamers \& Downs (2004) [41] Most HIV infections diagnosed in migrants probably acquired in country of origin. UK: $75 \%$ of heterosexual infections diagnosed in 2002 probably acquired in Africa • Germany: new diagnoses in 2002 probably acquired in Africa • Germany: new diagnoses
increased in 2002 among heterosexuals from countries with increased in 2002 among heterosexuals from countries with
generalised epidemics, majority infected in their countries of origin generalised epidemics, majority infected in their countries of origin
- Sweden: > $80 \%$ of HIV infections acquired through heterosexual contact were probably acquired abroad - Denmark: $37 \%$ of all diagnoses in 2002 were among migrants; $59 \%$ infected through heterosexual contact, most infected abroad. • Belgium: 4016/5515 of infections ever diagnosed in heterosexuals were in non-Belgiansmostly Africans.

Quality scores

Limitations

$\mathrm{SD}:+++\mathrm{V}:+++$

G: +++ OS: +++

Poor test specificity differentiating between subtypes $B$ and $D$ likely to be a significant factor in limiting the use of serotyping among black Africans. No standardized prospective data collection. Designation of likely country of infection based, on poorly documented variables from medical records (possible reporting bias). Findings may represent an underestimate of number of infections acquired through overseas travel.

SD: $+++\mathrm{V}:+++$ G: +++ OS: +++

SD: $+++V_{:}+++$ $\mathrm{G}:+++$ OS: +++ G: +++ OS: ++

$\mathrm{SD}:+++\mathrm{V}:+++$ G: +++ OS: +++

$\mathrm{SD}:+++\mathrm{V}:++$ G: +++ OS: ++

SD: $+++\mathrm{V}:++$ G: +++ OS: +++
Acquisition of HIV in UK negatively associated with late presentation therefore findings may underestimate infection acquired in UK. Sample only includes Africans living in London, therefore may not be representative to all HIV positive Africans in the UK

The search strategy includes only articles in English; research in other languages, the grey literature and conference abstracts not included.

ncomplete data in some variables (country of birth and infection in the new diagnosis study). Heterogeneous population compared for each of the outcomes.

Heterosexual transmission of HIV among Caribbeans within UK likely to be underestimated. If exposure to HIV has occurred in more than one country, the country with the highest prevalence will be assigned the likely country of infection. Missing data about country of birth may have had an impact on the review.

Country of Birth unknown for almost $50 \%$ of sample; results may underestimate the number of diagnosis among MSM born abroad \& proportion of MSM infected abroad because of clinician and patient reporting bias. Unclear whether permanent migrants or visitors.

Based on secondary data. No clear that reviewed literature was quality assessed. 
Table 3 Outcomes and limitations of included studies (Continued)

Lot et al. (2004) [14] Patients infected through heterosexual transmission: 690 patients (47\% from SSA). No data on the nationality or ethnicity of MSM - Proportion of recent infections among heterosexuals: SSA $26 \%$ vs France $44 \%(p=0.0001)$.

Pezzoli et al. (2009) [12]

HIV-1 detected in 0.97 of participants (95 \% Cl 0.90-1.2) - Avidity Testing ( $n=27)$ Six (22.2\%) probably acquired in Italy by migrants from: SSA $(n=3)$, eastern Europe $(n=2)$, and Latin America $(n=1)$. All $4(14.8 \%)$ who acquired infection before migration were migrant SSA.

Rice et al. (2012) [18] Probable place of infection: $33 \%$ (26\%-39\%) acquired HIV while living in the UK . Percentage increased from $24 \%(16 \%-39 \%)$ in 2004 to $46 \%(31 \%-50 \%)$ in 2010 $(p<0.01)$

Rice et al. (2014) [19]

Probable country of infection: The percentage of BA heterosexual adults probably acquiring HIV in the UK increased from $9.1 \%$ (276/3019) in 2002 to $37 \%(444 / 1202)$ in $2011(P<0.01)$

Semaille et al. (2008) [13] Proportion recent infections: French heterosexuals $27 \%$, SSA heterosexuals $8.4 \%$. OR for French (Ref.SSA): 3.95 (3.36-4.64).

Sinka K et al. (2003) [4] Probable Country of Infection for black African and black other $(n=7741)$ : UK or Rest of Europe 523/ $(6.76 \%)$ Africa: $6163(79.6 \%)$.

Staehelin et al. (2004) [42] Infection pre- migration ("with great certainty "or "presumably") SSA: $78(86.5 \%)$ SEA: $13(50.5 \%) \cdot$ Infection post-migration SSA: 2 (2.2\%) SEA: 6 (25\%).

Valin, et al. (2004) [43]

Probable country of infection: $44 \%$ SSA, $29 \%$ France, $27 \%$ unknown country.

von Wyl V et al. (2011)* [20] Proportion of non-B subtype viruses: Increased from $22 \%$ in 1996 to $33 \%$ in 2009 . Over $80 \%$ of all non-B infections among Africans may have originated outside of Switzerland: $20 \%$ of all sequences from this group were contained within Swiss-specific clusters.

Xiridou et al. (2010) [16] "New" Infections (Estimated 1.50 new infections/100,000 people/year): $53 \%$ of new infections among migrant Africans (32\% acquired in The Netherlands), $26 \%$ among Caribbean Migrants (18\% acquired in the Netherlands).

Xiridou et al. (2011) [17] Incidence of HIV among heterosexuals:1.50 new infections per 100,000 individuals per year in 2010 (infections occurring as a result of sexual contacts in The Netherlands or during trips of migrants to their home country). Sub-group
$\mathrm{SD}:+++\mathrm{V}:+++$

$\mathrm{G}:+++\mathrm{OS}:$

$\mathrm{SD} \cdot+++\mathrm{V} \cdot+++$ G: +++ OS: ++

$\mathrm{SD}:+++\mathrm{V}:+++$ G: +++ OS: +++

SD: +++ V: +++ $\mathrm{G}:+++$ OS: +++

$\mathrm{SD}:+++\mathrm{V}:+++$ G: +++ OS: ++

$\mathrm{SD}:+++\mathrm{V}:++$ $\mathrm{G}:+++$ OS: ++

$\mathrm{SD}:+++\mathrm{V}:+++$ G: +++ OS: +++

SD: $++\mathrm{V}:++$ G: +++ OS: ++

SD: $+++\mathrm{V}:+++$ G: +++ OS: +++

SD: $+++\mathrm{V}:+++$ G: +++ OS:++

SD: $+++\mathrm{V}:+++$ G:N/A OS: ++
Based on preliminary data. Late reporting and longer follow-up periods could show larger differences in recent infections. Additionally, the authors do not report on the ethnicity of patients just country of origin. No data on the nationality of MSM or IDUs.

Recruitment was not evenly balanced between centres; the study acceptance rate was $73.6 \%$. Place of infection could not be determined for 17 (63.0\%) of 27 persons (this is presumably due to recall bias). Very small sample size for avidity testing.

CD4 cell method may over estimate UK as place of infection since the longer a person is in the UK, the more likely they are to have been assigned UK as place of infection, despite travel habits and behaviour. Missing data for approximately $40 \%$ of eligible adults. Unclear robustness of model used to calculate date of infection.

Definition of heterosexual is based on probable route of infection as reported by clinics, and there is potential for misclassification. (See above for limitations in assigning country of infection).

Difficult of interpret available data.

imitations of surveillance data due to missing variables, particularly country of birth, ethnicity and country of acquisition. Heterosexual transmission underestimated due to how this data is recorded.

Source of infection not analysed because of poor availability of data. Sample size of SSA: only 92 patients. The robustness of the methodology for "Time of HIV-infection and migration" was not discussed directly; authors cite evidence there is no difference in the natural history of HIV infection in patients of differing ethnicity.

Proportion of patients who arrived in France after 1999 (34 \%) overestimated Study population includes naturalized citizens; is not representative of the entire the HIV-positive population originating from sub-Saharan Africa and living in France. Some questionnaire items may be subject to reporting bias.

Sampling bias (substantially alleviated by the high representativeness of the SHCS), linkage between individuals can never be established with absolute certainty

Data used in model taken from different studies, therefore difficulty to assess research quality.

Model does not take into account differences between 1st and 2nd generation migrants. 
Table 3 Outcomes and limitations of included studies (Continued)

\begin{tabular}{|c|c|c|c|}
\hline & $\begin{array}{l}\text { analysis } 67.18 \text { new infections/100,000 African migrants, } \\
12.12 / 100,000 \text { Caribbean migrants, } 0.47 / 100,000 \text { Dutch local. }\end{array}$ & & \\
\hline Elford et al. (2007) [26] & $\begin{array}{l}\text { Assortative Mixing: } 80 \% \text { of BA heterosexual men and } \\
\text { women reported sexual partners were also BA. }\end{array}$ & $\begin{array}{l}\text { SD: }+++ \text { V: }+++ \\
\text { G: }+++ \text { OS: }+++\end{array}$ & $\begin{array}{l}\text { High-risk sexual behaviours may be underreported because of social } \\
\text { desirability bias or because of the associated stigma. Selection bias from } \\
\text { response rate; not broadly representative of those living with HIV as sample } \\
\text { exclusively from London. }\end{array}$ \\
\hline Holguin et al. (2007) [21] & $\begin{array}{l}\text { Prevalence of HIV-1 non-B subtypes and recombinants } 40 \\
(28.8 \%) \text { samples, Migrants: } 28(53 \% \text { of all migrants in } \\
\text { study - } 75 \% \text { acquired their infection through sexual } \\
\text { contact with people born in African) Native Spaniards: } \\
12 \text { ( } 13.7 \% \text { of all native Spaniards in the study - } 4 \text { most } \\
\text { likely acquired HIV-1 through unprotected sex in sub } \\
\text { Saharan Africa; } 3 \text { with Africans residing in Spain; } 2 \text { with } \\
\text { partners from Spain; } 2 \text { sexual contact with sex workers } \\
\text { and } 1 \text { MSM with multiple partners). }\end{array}$ & $\begin{array}{l}\text { SD: }+ \text { V: }++\mathrm{G}:+ \\
\text { OS: }++\end{array}$ & $\begin{array}{l}\text { Number of non-B subtypes among newly diagnosed native individuals is } \\
\text { biased and could be underestimated. Subtyping of a large number of } \\
\text { samples would be required to determine if the incidence of HIV- } 1 \text { non-B } \\
\text { variants is increasing over time in the newly diagnosed native population. }\end{array}$ \\
\hline Kramer (2008) [29] & $\begin{array}{l}\text { Sexual mixing (sexual partner with differing ethnicity) High } \\
\text { risk }=42 \% \text { ( } 84 \% \text { unprotected), Moderate risk }=59 \% \\
\text { (no data), Low risk }=66 \% \text { (no data). }\end{array}$ & $\begin{array}{l}\text { SD: }+++V:++ \\
\text { G: }++ \text { OS: }++\end{array}$ & $\begin{array}{l}\text { Convenience sample and social desirability bias Includes both first generation } \\
\text { and second generation migrant with no distinction drawn between them } \\
\text { in analysis. }\end{array}$ \\
\hline Lai (2013) [24] & $\begin{array}{l}\text { Sexual mixing: } 50 \% \text { of men and } 47 \% \text { of women reported } \\
\text { partners born in different countries. Most partners from } \\
\text { a different African country (men } 19 \% \text {; women } 20 \% \text { ). }\end{array}$ & $\begin{array}{l}\text { SD: }+ \text { V: }++\mathrm{G}:+ \\
\text { OS: }++\end{array}$ & $\begin{array}{l}\text { Convenience sample; low response rate }(14 \%) \text {; desirability bias; data does } \\
\text { not support some conclusions reached in the discussion. }\end{array}$ \\
\hline Marsicano et al. (2013) [28] & $\begin{array}{l}\text { Factors associated with epidemiological networks: Country } \\
\text { of origin independently associated with the probability of } \\
\text { isolates being detected in clusters OR for Italian vs. African } \\
\text { origin: } 5.3,95 \% \text { Cl: } 2.2-12.9, P<0.001 ; \text { South American vs. } \\
\text { African origin: } 25.6,95 \% \text { Cl: } 2.0-162.0, P<0.001 \text {. }\end{array}$ & $\begin{array}{l}\text { SD: }+++V:++G:++ \\
\text { OS: }+++\end{array}$ & $\begin{array}{l}\text { ARCA database has relative lack of country of origin and risk factor information } \\
\text { for some patients which could have weakened the strength of the detected } \\
\text { associations. Clusters were probably underestimated and incomplete due to } \\
\text { missing data. }\end{array}$ \\
\hline Rivas (2013) [25] & $\begin{array}{l}\text { Proportion of B subtypes: Total } 4 \text { ( } 3.3 \%) \text {; Migrants from } \\
\text { Equatorial Guinea } 2(2.9 \%) \text {; sub Saharan Africa; } 1(5.6 \%) P=0.47 .\end{array}$ & $\begin{array}{l}\text { SD: }++ \text { V:++ G:++ } \\
\text { OS:++ }\end{array}$ & $\begin{array}{l}\text { Sample disproportionately represented by women and elderly people so } \\
\text { might not reflect wider Equatorial Guinea community. Poor justification for } \\
\text { some conclusions e.g. low CD4 cell counts = imported infections. }\end{array}$ \\
\hline Snoeck et al. (2002) [22] & $\begin{array}{l}\text { Country of Infection: } 45 \% \text { Africa, } 2 \% \text { South-America, } \\
6 \% \text { rest of Europe or USA. } \cdot \text { Origin of the virus }(P=0.0004) \text { : } \\
\text { Belgium (19) Subtype } B=16 ; \text { Non- } B=3 \text {; Other }(22) \\
\text { Subtype } B=3 \text {; Non- } B=19 \cdot \text { No association between } \\
\text { nationality and subtype }(P=0.06) \text {. }\end{array}$ & $\begin{array}{l}\text { SD: }+++V:++G:++ \\
\text { OS: }++\end{array}$ & $\begin{array}{l}\text { Small sample size. Disproportionate numbers of female non-Belgians than } \\
\text { male non-Belgians in the study population may have introduced a bias. }\end{array}$ \\
\hline Tramutoet al (2013) [23] & $\begin{array}{l}\text { Proportion of non-B subtypes:; } 107(69.0 \%) \text { were infected } \\
\text { with B strains, whereas non-B subtypes were detected in } \\
48 \text { subjects }(31.0 \%) \text {.Only } 9.7 \%(n=11 / 113) \text { of Italian-born } \\
\text { subjects were infected with non-B HIV-1 variants. } 3 \text { (7.9\%) } \\
\text { Africans were infected with B subtypes. }\end{array}$ & $\begin{array}{l}\text { SD: }+++ \text { V: }+++ \\
\text { G: }++ \text { OS: }+++\end{array}$ & $\begin{array}{l}\text { Data does not support some of the conclusions. Authors do not acknowledge } \\
\text { limitations of surveillance data. }\end{array}$ \\
\hline van Veen et al. (2009) [27] & $\begin{array}{l}\text { Sexual mixing: Partners from the same ethnicity } 59 \% \text {, } \\
\text { Partners with differing ethnicity } 41 \% \text { ( } 15 \% \text { with Dutch } \\
\text { partners; } 21 \% \text { with partners of "Other" ethnicity; } 5 \% \\
\text { with both Dutch and "Other"). }\end{array}$ & $\begin{array}{l}\text { SD: }+++ \text { V: }+++ \\
\text { G: }++ \text { OS: }+++\end{array}$ & Desirability bias; convenience sample; auto-selection bias. \\
\hline
\end{tabular}

$\mathrm{BA}=$ Black African, BC= Black Caribbean, SSA = Sub Saharan African, SEP = Socioeconomic Position, MSM = Men who have sex with men SD=Study Design, V=Validity, G = Generalisability, OS = Overall Score, $\mathrm{N} / \mathrm{A}=$ Not applicable 
Table 4 Proportion of infections acquired in European countries among people born in Africa or with Black African ethnicity

\begin{tabular}{llll}
\hline Author and year & Country/City/Region & Profile & Proportion \\
\hline Aggarwal I (2006) [32] & London (UK) & Black African & 11 \\
Burns FM (2009) [38] & London (UK) & African & $25-35$ \\
Dougan S (2005) [15] & England and Wales & MSM black African & 39 \\
Dougan S (2005) [39] & England and Wales & MSM born in Africa & 46 \\
Rice BD (2012) [18] & England, Wales, Northern Ireland & Black African & 29 \\
Rice BD (2014) [19] & England, Wales, Northern Ireland & Black African & 37 \\
Sinka K (2003) [4] & United Kingdom & Black African & 3 \\
Staehelin C (2004) [42] & Switzerland & Sub-Saharan African & 2 \\
Valin, N (2000) [43] & lle-de-France (France) & Sub-Saharan African & 29 \\
Xiridou M (2010) [16] & Netherlands & African migrants & 32 \\
\hline
\end{tabular}

ethnicity and van Veen et al. (2009) [27] found that $41 \%$ of their sample had partners with different ethnicity $(15 \%$ with Dutch partners). Similarly Marisciano et al. (2013) reported that $50 \%$ of men and $47 \%$ of women had partners from a different country although most were from another African country [28].

In a cross sectional survey examining sexual behaviour among Surinamese and Antillean migrants in the Netherlands [29], the authors describe travel patterns of migrants and provide estimates of sexual mixing for a population they classified as having the potential to provide a transmission "bridge" between the Caribbean and The Netherlands. Those having unprotected sex in both countries, the so-called "bridge population", reported partners of a different ethnicity less often than those in moderate or low risk groups (42\%, $59 \%$ and $66 \%$ respectively) [29].

\section{Member states survey}

Twenty-four countries responded to the survey (response rate: $80 \%$ ). Five countries reported having data on sexual transmission of HIV among migrant communities. Denmark and Germany provided some contextual information about sexual transmission of HIV, but were unable to provide estimates of the proportion of migrants acquiring their HIV post-migration. The Netherlands provided grey literature and peer reviewed papers (subsequently included in the literature review) showing within-country sexual transmission among migrant communities. The most specific data came from Norway (14\% of 152 migrants diagnosed with HIV in 2011 were thought to have acquired their HIV infection post-migration) and the UK, (see Rice et al.[18]).

The remaining member state respondents did not provide data on, or estimates of, sexual transmission of HIV among migrant communities.

\section{Ascertaining probable country of infection}

Fifteen countries include a Probable Country of Infection (PCOI) data field in their new diagnoses database. Survey respondents reported that PCOI is established by direct interview of the case or indirectly through a clinician report. A range of data are used to assign PCOI - in particular a combination of clinical (such as CD4 count and viral load at diagnosis) as well patient demographic information

Table 5 Proportion of infections acquired in European countries among people born in Caribbean or Asia or with Black Caribbean ethnicity

\begin{tabular}{|c|c|c|c|}
\hline Author and year & Country/City/Region & Profile & Proportion \\
\hline Aggarwal I (2006) [32] & United Kingdom & Black Caribbean & 62 \\
\hline Dougan S (2004) [40] & England, Wales, and Northern Ireland & Black Caribbean male heterosexuals & 24 \\
\hline Dougan S (2004) [40] & England, Wales, and Northern Ireland & Black Caribbean women & 41 \\
\hline Dougan S (2004) [40] & England, Wales, and Northern Ireland & Black Caribbean MSM & 62 \\
\hline Dougan S (2005a) [15] & England and Wales & MSM black Caribbean & 61 \\
\hline Dougan S (2005b) [39] & England and Wales & MSM born in Caribbean & 43 \\
\hline Dougan S (2005b) [39] & England and Wales & Asia-born MSM & 61 \\
\hline Pezzoli MC (2009) [12] & Italy & Sub Saharan African, Eastern Europe and Latin America & 22 \\
\hline Rice B D (2012) [18] & England, Wales, Northern Ireland & Black Caribbean & 59 \\
\hline Staehelin C (2004) [42] & Switzerland & Southeast Asian & 25 \\
\hline Xiridou M (2010) [16] & The Netherlands & Caribbean migrant & 18 \\
\hline
\end{tabular}


(COB and Date of Arrival). Thirteen countries collect enough data to use the CD4-cell based method of calculating PCOI developed by Rice et al. (2012) (Belgium, Denmark, France, Greece, Italy, Lithuania, Luxembourg, Malta, Portugal, Romania, Slovak Republic, Sweden, UK).

\section{Discussion}

This study draws together evidence on the extent to which sexual acquisition of HIV is occurring among migrants from countries with a generalised HIV epidemic after they have moved to the EU/EEA. Despite this systematic review of the literature, survey of EU/EEA Member states, and data reported by countries as part of monitoring the Dublin Declaration which all provide some evidence, it remains difficult to gain an accurate picture for the EU/ EEA. The published literature is relatively sparse: $27 \mathrm{pa}-$ pers were retrieved from just seven countries. PanEuropean studies were also included, but these were low on detail and did not provide specific estimates.

The data do provide evidence of on-going post-migration HIV acquisition, most notably by providing estimates of probable country of acquisition or of incident infection. The methodology for calculating these estimates varied across studies, making it difficult to assess their reliability and comparability. Figures for HIV infections contracted post-migration ranged from as low as $2 \%$ among sub Saharan Africans in Switzerland, to $62 \%$ among black Caribbean MSM in the UK. As this example demonstrates, study populations varied, with some samples based on country of birth, others ethnicity and some using both definitions as surrogate markers for migration. Such heterogeneity in the retrieved data makes it difficult to construct a succinct and clear understanding of on-going sexual acquisition and transmission, both within host countries or across the EU/EEA. Nonetheless, all studies found that post-migration acquisition of HIV is occurring and this must be measured and understood in order to adequately meet the HIV prevention needs of migrant communities.

It is possible that limitations in our review methodology prevented us retrieving relevant information. We were unable to include papers published in languages outside our language skill set. No papers were retrieved from the eastern part of the EU, though this is not unexpected as Eastern Europe does not have a large population of migrants from countries with a generalised HIV epidemic. A survey of EU/EEA Member States combined with data captured through the monitoring of the Dublin Declaration on Partnership to Fight HIV/AIDS in Europe and Central Asia were expedient and costeffective ways of gathering data about specific countries. Nonetheless, these often relied on the knowledge and experience of one representative from a national body who may not have had all relevant information at their disposal.

\section{Implications for HIV surveillance}

Understanding and quantifying HIV transmission in a given population is complex. Effective practice would be to monitor trends in HIV incidence, but these measures are not straightforward and are often beyond the scope of routine surveillance systems. Trends in new HIV diagnoses are sometimes used as a proxy for incident cases, but these are also subject to testing biases as they are dependent on high uptake of regular HIV testing in the population of interest. New tests of recent or incident infections may provide greater insights into real time transmission dynamics. Another challenge is specific to HIV surveillance among migrant communities. Migration as a process is not static, and many migrants travel backwards and forward between their country of origin and country of residence, making estimates of place of infection subject to measurement error. Studies addressing sexual mixing patterns and sexual activity of migrants from countries with generalised epidemics do not necessarily make the best proxies when attempting to find evidence about probable country of HIV acquisition. For example, the increasing proportion of non-B subtypes shown in these papers may reflect on-going migration rather than post-migration HIV acquisition or transmission.

This study found that many more member states collect data that could be used in an objective method for assigning Probable Country of Infection than is expected from the published data. The lack of published evidence could indicate that this is an area requiring technical support to EU/EEA Member States to carry out this work. Additionally, it is possible that some publication bias exists, with authors unable or unwilling to publish data on a sensitive topic that may have a stigmatising impact on migrant communities particularly within the context of Europe's ongoing immigration debate [7, 30].

EU/EEA Member States might be encouraged to analyse and publish such data if standardised methods of calculating Probable Country of Infection were developed and implemented in surveillance systems across the region. To achieve this a minimum dataset of CD4 cell count at diagnosis, date or year of arrival and country of birth on all newly diagnosed persons are likely to be required. In some settings, sentinel surveillance or repeat cross sectional surveys, could play an important role in providing this necessary evidence. Member States might also be encouraged to publish data if they formed meaningful partnerships with migrant and/or minority ethnic community organisations who could provide support and guidance about how to disseminate data sensitively [31]. Data relevant to post-migration sexual acquisition 
could then be used to plan and monitor HIV programmes that meet the needs of migrant communities in Europe.

\section{Implications for prevention programming}

Given the evidence for post-migration HIV acquisition among migrant groups in some EU/EEA Member States, there is a need for increased awareness among policymakers of the HIV prevention needs of migrants from countries with generalised epidemics. This awareness will require additional attention and resources to improve primary prevention programmes targeted to the specific (culturally appropriate) needs of various migrant communities.

Many migrants remain sexually active during transit and after they have reached their destination country. Papers examining sexual mixing present evidence that the number and proportion of non-B HIV-1 subtypes are increasing in non-migrants and established minority ethnic communities across Europe [20-22, 32]. The propensity for assortative sexual mixing means that people from countries with generalised epidemics may continue to live in a community with a generalised epidemic even after they have moved to Europe, but be unaware of their HIV prevention needs in their new home.

Migrant MSM appear at particular risk of HIV acquisition post-migration. Behavioural data suggests assortative sexual mixing according to country of origin or ethnicity is not a prevailing feature of sex between men [33] as reflected in the predominance of B subtypes in these communities [32]. Acquisition of viral clades not prevalent in home countries supports post-migration acquisition and (as with heterosexual men) this highlights the need for primary prevention programs targeting these communities. Effective HIV prevention interventions would need to recognise that many MSM from countries with a generalised epidemic may not selfidentify as gay men or disclose their sexual identity [34]. Surveillance data does not routinely report on migrant MSM and as such are unable to inform prevention programmes for this population.

\section{Implications for policy}

Countries who identify migrants as an important part of their country's HIV epidemic should consider developing an evidence-based, long-term policy to introduce prevention programmes that reduce HIV-acquisition in these groups. To reduce acquisition countries would need to include policies around structural, behavioural and biomedical prevention interventions that are targeted to all communities, including migrants from countries with generalised epidemics.

Approximately half of the EU/EEA countries surveyed report that they do not provide ART to irregular/ undocumented migrants, that is, to persons that cannot legally reside in the country [35]. Treatment as a means of reducing sexual transmission of HIV now forms a key part of the prevention paradigm, like other conditions of paramount public health importance such as tuberculosis [36]. However, policy responses such as mandatory screening contravene the WHO policy framework for HIV testing in Europe which states mandatory HIV testing for migrants and asylum seekers upon arrival violates basic rights and ethical principles and cannot be justified on public health grounds [37]. Improving access to HIV treatment for all infected persons, regardless of their administrative and or immigration status, could positively impact on reducing incident infections both within and beyond migrant communities. This would necessitate addressing the already identified barriers to HIV prevention, testing and care that exist for migrant communities [31]. Failure to ensure access to HIV treatment for all persons in need could prove detrimental to efforts to ameliorate the HIV epidemic.

\section{Conclusion}

There is limited published evidence about the acquisition of HIV within Europe among migrants from countries with a generalised epidemic. Individuals are certainly contracting HIV through sexual contact after they have moved to Europe and MSM appear to be at particular risk of postmigration HIV acquisition, yet this is rarely acknowledged within the literature. Only a few countries collect and publish data to enable robust estimates to quantify or monitor the place of HIV infection, which may have a detrimental impact on HIV prevention interventions.

The majority of countries that identify migrants as an important at risk population for HIV infection have put in place measures to estimate the distribution of HIV in these groups. Despite the many areas of concordance and agreement in Member States surveillance systems there remain a number of gaps in the processing and availability of this data. This therefore limits the ability of policymakers and programme managers who wish to have an impact on HIV incidence at country and regional levels.

\section{Endnotes}

${ }^{1}$ The search was updated on 9th January 2015 to include articles published between January 2012 and December 2014.

${ }^{2}$ These are EU/EFTA countries: Austria; Belgium; Bulgaria; Cyprus; Czech Republic; Denmark; Estonia; Finland; France; Germany; Greece; Hungary; Iceland; Republic of Ireland; Italy; Latvia; Liechtenstein; Lithuania; Luxembourg; Malta; The Netherlands; Norway; Poland; Portugal; Romania; Slovakia; Switzerland; Slovenia; Spain; Sweden; UK. 
${ }^{3}$ European Centre for Disease Prevention and Control. Thematic report: Migrants. Monitoring implementation of the Dublin Declaration on partnership to fight HIV/ AIDS in Europe and Central Asia: 2012 Progress Report. Stockholm: ECDC; 2013.

\section{Competing interests}

The author(s) declare that they have no competing interests.

\section{Authors' contributions}

IF led the systematic review, acted as a reviewer (data extraction and quality assessment) and wrote the initial draft of the paper. DDA acted as a reviewer (data extraction and quality assessment) and wrote sections of the paper. MWO designed and conducted the survey and wrote sections of the paper. SM \& YRM acted as reviewers (data extraction and quality assessment) and commented on drafts of the paper. VD led the development and analysis of the survey and contributed to writing the final paper. BR coordinated the survey analysis and contributed to writing the final paper. TN \& AP were involved in the project design and wrote sections of the paper. AAG commented on the final draft on the paper. JDA provided supervisory and expert support and reviewed the final paper. FB had overall management responsibility for the project, acted as a reviewer in study selection, reviewed the survey instrument and contributed to writing the final paper. All authors read and approved the final manuscript.

\section{Acknowledgements}

This study was commissioned and funded by the European Centre for Disease Prevention and Control (ECDC). A full report, including all methodological details can be found here: http://ecdc.europa.eu/en/ publications/Publications/Migrant-health-sexual-transmission.pdf. As this paper is based in part on data submitted by countries, we would like to thank all those who contributed. These were: Andre Sasse (Belgium), Avgi Hadjiloukas (Cyprus), Osamah Hamouda (Germany), Susan Cowan (Denmark), Kristi Rüütel (Estonia), Mercedes Diez (Spain), Caroline Semaille (France), Kirsi Liitsola (Finland), Maria Dudas (Hungary), Dimitra Paraskeva and Georgios Nikolopoulos (Greece), Derval lgoe (Ireland), Haraldur Briem and Guðrún Sigmundsdóttir (Iceland), Ingrida,Sniedze and Šarlote Konova (Latvia), Irma Čaplinskiene (Lithuania), Barbara Suligoi (Italy), Jean-Claude Schmit (Luxembourg), Jackie Maistre Melillo and Tanya Melillo French (Malta),Eline Op de Coul (Netherlands), Hans Blystad (Norway), Magdalena Rosinska (Poland), Mariana Mardarescu (Romania), Peter Truska (Slovak Republic), Frida Hansdotter (Sweden), and Valerie Delpech (United Kingdom).

\section{Author details}

${ }^{1}$ Centre for Sexual Health and HIV Research, Research Department of Infection and Population Health, University College London, Mortimer Market Centre, off Capper Street, London WC1E 6JB, UK. ${ }^{2}$ National Centre of Epidemiology, Instituto de Salud Carlos III, Madrid, Spain. ${ }^{3}$ Department of Health and Socio-medical Sciences, University of Alcalá, Alcalá de Henares, Madrid, Spain. ${ }^{4}$ Ciber de Epidemiologia y Salud Publica (CIBERESP), Barcelona, Spain. ${ }^{5}$ IIV \& STI Department, Health Protection, Public Health England, England, UK. 'European Centre for Disease Prevention and Control, Solna, Sweden. 'Royal Free London NHS Foundation Trust, Pond Street, London NW3 2QG, UK.

Received: 24 July 2014 Accepted: 19 May 2015

Published online: 19 June 2015

\section{References}

1. Fernandes A, Miguel J: Health and Migration in the European Union: Better Health for All in an Inclusive Society. Lisbon 2007. In: http://www.insa.pt/ sites/INSA/Portugues/Publicacoes/Outros/Documents/Epidemiologia/ HealthMigrationEU2.pdf 2007.

2. European Centre for Disease Prevention and Control (ECDC), WHO Regional Office for Europe: HIV/AIDS surveillance in Europe 2013. In: http:// ecdc.europa.eu/en/publications/Publications/hiv-aids-surveillance-reportEurope-2013.pdf 2012.

3. del Amo J, Pérez-Cachafeiro S, Hernando V, González C, Jarrin I, Bolúmar F: Migrant health: Epidemiology of HIV and AIDS in migrant communities and ethnic minorities in EU/EEA countries. In: http://ecdc.europa.eu/en/
publications/Publications/0907_TER_Migrant_health_HIV_Epidemiology_ \#review.pdf 2010.

4. Sinka K, Mortimer J, Evans B, Morgan D. Impact of the HIV epidemic in subSaharan Africa on the pattern of HIV in the UK. AIDS. 2003;17(11):1683-90.

5. European Centre for Disease Prevention and Control (ECDC), WHO Regional Office for Europe: HIV/AIDS surveillance in Europe 2011. In: http://ecdc.europa.eu/ en/publications/Publications/20121130-Annual-HIV-Surveillance-Report.pdf 2012.

6. Jarrin I, Pantazis N, Gill MJ, Geskus R, Perez-Hoyos S, Meyer L. Uptake of combination antiretroviral therapy and HIV disease progression according to geographical origin in seroconverters in Europe, Canada, and Australia. In: Clinical infectious diseases : an official publication of the Infectious Diseases Society of America Clinical Infectious Diseases. vol. 2011/11/24. 2012. p. $111-8$.

7. National AIDS Trust. The Myth of HIV Health Tourism. London: NAT; 2008

8. Cole P. Human rights and the national interest: migrants, healthcare and social justice. Journal of medical ethics. 2007;33(5):269-72.

9. European Centre for Disease Prevention and Control. Migrant health: Sexual transmission of HIV within migrant groups in the EU/EEA and implications for effective interventions. Stockholm: ECDC; 2013

10. Moher D, Liberati A, Tetzlaff J, Altman DG, Group P. Preferred reporting items for systematic reviews and meta-analyses: the PRISMA statement. PLOS Med. 2009;6(7):e1000097.

11. National Institute for Health and Clinical Excellence. Methods for the development of NICE public health guidance. Secondth ed. London: NICE; 2009.

12. Pezzoli MC, Hamad IE, Scarcella C, Vassallo F, Speziani F, Cristini G, et al. HIV infection among illegal migrants, Italy, 2004-2007. Emerging Infectious Diseases. 2009;15(11):1802-4.

13. Semaille C, Cazein F, Pillonel J, Lot F, Le VS, Pinget R, et al. Four years of surveillance of recent HIV infections at country level, France, mid 2003-2006: experience and perspectives. Euro Surveill. 2008;13(36):2008.

14. Lot F, Semaille C, Cazein F, Barin F, Pinget R, Pillonel J, et al. Preliminary results from the new HIV surveillance system in France. Euro Surveill. 2004;9(10):34-7.

15. Dougan S, Elford J, Sinka K, Fenton KA, Evans BG. Men who have sex with men who are born abroad and diagnosed with HIV in England and Wales: an epidemiological perspective. Int J STD AIDS. 2005;16(9):618-21.

16. Xiridou M, van VM, Coutinho R, Prins M. Can migrants from high-endemic countries cause new HIV outbreaks among heterosexuals in low-endemic countries? AIDS. 2010;24(13):2081-8.

17. Xiridou $M$, van Veen MG, Prins $M$, Coutinho R. How patterns of migration may influence heterosexual HIV transmission. Sexually Transmitted InfectionsConference: 19th Biennial Conference of the International Society for Sexually Transmitted Diseases Research Quebec City, QC CanadaConference Start: 20110710 Conference End: 20110713Conference Publication: (varpagings. 2011;87:A154.

18. Rice BD, Elford J, Yin Z, Delpech VC. A new method to assign country of HIV infection among heterosexuals born abroad and diagnosed with HIV. AIDS. 2012;26(15):1961-6.

19. Rice B, Elford J, Yin Z, Croxford S, Brown A, Delpech V. Trends in HIV diagnoses, HIV care, and uptake of antiretroviral therapy among heterosexual adults in England, Wales, and Northern Ireland. Sex Transm Dis. 2014;41(4):257-65.

20. von Wyl V, Kouyos RD, Yerly S, Boni J, Shah C, Burgisser P, et al. The role of migration and domestic transmission in the spread of HIV-1 non-B subtypes in Switzerland. Journal of Infectious Diseases. 2011;204(7):1095-103.

21. Holguin A, Pena MJ, Troncoso F, Soriano V. Introduction of non-B subtypes among Spaniards newly diagnosed with HIV type 1 in the Canary Islands. AIDS Research \& Human Retroviruses. 2007;23(4):498-502.

22. Snoeck J, Van DS, Van LK, Derdelinckx I, Van WE, De CE, et al. Prevalence and origin of HIV-1 group M subtypes among patients attending a Belgian hospital in 1999. Virus Research. 2002;85(1):23.

23. Tramuto F, Maida CM, Bonura F, Perna AM, Vitale F, Tramuto F - F. Dynamics and molecular evolution of HIV-1 strains in Sicily among antiretroviral naive patients. Infect Genet Evol. 2013;16:290-7.

24. Lai A, Bozzi G, Franzetti M, Binda F, Simonetti FR, Micheli V, et al. Phylogenetic analysis provides evidence of interactions between Italian heterosexual and South American homosexual males as the main source of national HIV-1 subtype C epidemics. J Med Virol. 2014;86(5):729-36.

25. Rivas P, Herrero MD, Poveda E, Madejon A, Trevino A, Gutierrez M, et al. Hepatitis B, C, and D and HIV infections among immigrants from Equatorial Guinea living in Spain. Am J Trop Med Hyg. 2013;88(4):789-94. 
26. Elford J, Ibrahim F, Bukutu C, Anderson J: Sexual behaviour of people living with HIV in London: implications for HIV transmission. AIDS 2007, 21:Suppl 1:S63-70.

27. van Veen MG, Kramer MA, Op de Coul EL, van Leeuwen AP, de ZO, Vande Laar MJ, et al. Disassortative sexual mixing among migrant populations in The Netherlands: a potential for HIV/STI transmission? AIDS care. 2009;21(6):683-91.

28. Marsicano E, Lydie N, Fa BN, Marsicano E. 'Migrants from over there' or 'racial minority here'? Sexual networks and prevention practices among sub-Saharan African migrants in France. Cult Health Sex. 2013;15(7):819-35.

29. Kramer MA, van Veen MG, de Coul EL, Geskus RB, Coutinho RA, van de Laar $\mathrm{MJ}$, et al. Migrants travelling to their country of origin: a bridge population for HIV transmission? Sex Transm Infect. 2008;84(7):554-5.

30. Meyer H: Myth And Reality In The European Migration Debate. In: http:// www.socialeurope.eu/2014/01/european-migration-debate/ Last Accessed: 6 January 2015

31. del Amo J, Álvarez D, Monge S, Caro A, Ramírez O, Pérez-Cachafeiro S, et al: Migrant health: HIV testing and counselling in migrant populations and ethnic minorities in EU/EEA/EFTA Member States. In: http://www.iss.it/ binary/ccoa/cont/HIV_in_migrants.pdf. 2011.

32. Aggarwal I, Smith M, Tatt ID, Murad S, Osner N, Geretti AM, et al.: Evidence for onward transmission of HIV-1 non-B subtype strains in the United Kingdom. Journal of Acquired Immune Deficiency Syndromes 2006, 41(2):February.

33. Evans AR, Hart GJ, Mole R, Mercer CH, Parutis V, Gerry CJ, et al. Central and east European migrant men who have sex with men: an exploration of sexual risk in the U.K. Sexually Transmitted Infections. 2011;87(4):325-30.

34. Paparini S, Doyal L, Anderson J. 'I count myself as being in a different world': African gay and bisexual men living with HIV in London. An exploratory study AIDS care. 2008;20(5):601-5.

35. European Centre for Disease Prevention and Control: Thematic report: Migrants. Monitoring implementation of the Dublin Declaration on Partnership to Fight HIV/AIDS in Europe and Central Asia: 2012 Progress Report. ECDC Stockholm; 2013.

36. Cohen MS, Chen YQ, McCauley M, Gamble T, Hosseinipour MC, Kumarasamy N, et al.: Prevention of HIV-1 Infection with Early Antiretroviral Therapy. In: New England Journal of Medicine. vol. 365: Massachusetts Medical Society; 2011: 493-505

37. World Health Organisation. Scaling up HIV testing and counselling in the WHO European Region as an essential component of efforts to achieve universal access to HIV prevention, treatment, care and support. Copenhagen. WHO Regional Office for Europe. 2010.

38. Burns FM, Arthur G, Johnson AM, Nazroo J, Fenton KA, group Sc. United Kingdom acquisition of HIV infection in African residents in London: more than previously thought. AIDS. 2009;23(2):262-6.

39. Dougan S, Elford J, Rice B, Brown AE, Sinka K, Evans BG, et al. Epidemiology of HIV among black and minority ethnic men who have sex with men in England and Wales. Sex Transm Infect. 2005;81(4):345-50.

40. Dougan S, Payne LJ, Brown AE, Fenton KA, Logan L, Evans BG, et al. Black Caribbean adults with HIV in England, Wales, and Northern Ireland: an emerging epidemic? Sexually Transmitted Infections. 2004;80(1):18-23.

41. Hamers FF, Downs AM. The changing face of the HIV epidemic in western Europe: What are the implications for public health policies? Lancet. 2004;364(9428):03.

42. Staehelin C, Egloff N, Rickenbach M, Kopp C, Furrer H: Migrants from sub-Saharan Africa in the Swiss HIV cohort study: A single center study of epidemiologic migration-specific and clinical features. AIDS Patient Care and STDs 2004;18(11):665-75.

43. Valin N, Lot F, Larsen C, Gouëzel P, Blanchon T, Laporte A: Parcours sociomédical des personnes originaires d'Afrique subsaharienne atteintes par le $\mathrm{VIH}$, prises en charge dans les hôpitaux d'lle-de-France, 2002. In: http://www.invs.sante.fr/publications/2004/vih_afrique/vih_afrique.pdf. 2002.

\section{Submit your next manuscript to BioMed Central and take full advantage of:}

- Convenient online submission

- Thorough peer review

- No space constraints or color figure charges

- Immediate publication on acceptance

- Inclusion in PubMed, CAS, Scopus and Google Scholar

- Research which is freely available for redistribution

Submit your manuscript at www.biomedcentral.com/submit 